\title{
Estimation of Flow Discharge Model at Temef Watershed - East Nusa Tenggara Using TRMM Satellite Data
}

\author{
Aprianto Nomleni ${ }^{1}$, Ery Suhartanto ${ }^{1}$, Donny Harisuseno ${ }^{1}$ \\ ${ }^{1}$ Water Resources Engineering Department, Faculty of Engineering, Universitas \\ Brawijaya, Malang, 65145. Indonesia. \\ anto_nom@yahoo.com \\ Received 22-03-2021; accepted 04-05-2021
}

\begin{abstract}
Data collection based on satellite TRMM (Tropical Rainfall Measuring Mission) presents one of the best alternatives in estimating rainfall. TRMM technology can minimize manual rainfall recording errors and improve rainfall accuracy for hydrological analysis. The analysis method used in this research is divided into 3 (three) stages, Hydrological analysis, Statistical Analysis and Artificial Neural Network Analysis. The TRMM JAXA analysis results in the Temef Watershed Area obtained TRMM JAXA satellite rainfall relationship to observation data shows rainfall patterns between the two data are interconnected. However, for cases with very high observation rainfall, TRMM rainfall data tend to be low. From the statistical method analysis, the relationship between observed rainfall and TRMM JAXA rainfall obtained results with a "Very Strong" interpretation indicated by the results of 9 years calibration and 1 year validation where the selected equation is a polynomial equation $(\mathrm{y}=$ $0.0123 \times 2+1.5553 x+20.222)$. Rain data correction results simulated with Debit data to see the relationship between rain and discharge that occurred, this analysis using Artificial Neural Network with Backpropagation method, the results showed a "Strong" interpretation where statistically the value of Nash-Sutcliffe Efficiency (NSE) is 0.920 . The Coefficient correlation is 0.877 and the relative error that occurred is $2.62 \%$.
\end{abstract}

Keywords: Artificial Neural Network, flow discharge, TRMM JAXA

\section{Introduction}

East Nusa Tenggara Province has four large islands, one of which is the island of Timor with an area of $\pm 14.200 \mathrm{~km}^{2}$ [1]. Climate conditions in East Nusa Tenggara are close to Australia, wind currents containing a lot of moisture from Asia and the Pacific Ocean in the East Nusa Tenggara region, so that the rainy days in East Nusa Tenggara are fewer than in areas close to Asia [7,13]. East Nusa Tenggara has dry climates, namely: climate type D3 (3-4 wet months and 4-6 dry months), climate type D4 (3-4 wet months and > 6 months dry), climate type E3 (6 dry months) [12]. Therefore, rainfall occurs in thunderstorms only a few times, causing flash floods and uncontrollable erosion, water is quickly dumped into the sea and little seeps into the ground.

Cite this as: Nomleni, A., Suhartanto, E., \& Harisuseno, D. (2021). Estimation of Flow Discharge Model at Temef Watershed - East Nusa Tenggara Using TRMM Satellite Data. Civil and Environmental Science Journal (Civense), 4(2), 115-126. doi: https://doi.org/10.21776/ub.civense.2021.00402.2 
Based on data from Presidential Decree No. 12 of 2012. One of the rivers in the province of East Nusa Tenggara, precisely in the south Central Timor Regency is included in the Benanain River Region and Noelmina river region. During the dry season, the large river area is relatively dry, while during the rainy season the water volume increases [18]. As a region with low rainfall, rainfall data in East Nusa Tenggara are often incomplete. Obstacles and problems that are still often encountered are the lack of space and time for observation of rainfall data, as well as the availability of time series and rainfall data that is not long enough and incomplete. In addition, the number of rain stations is uneven, and the lack of observers. Observation and data recording system is still done manually, data collection from certain areas to the central level is still hampered and running slowly, and the data format is not yet standard [10]. Satellite-based rainfall capture presents an alternative way that can measure rainfall through spacecraft sensors and algorithms [11]. Satellite-based rainfall data are widely used due to the relatively high accuracy rate [14], e.g. Tropical Rainfall Measuring Mission (TRMM) or Multi-Satellite Rainfall Product Analysis (TMPA) data. TRMM satellite used is JAXA (Japan Aerospace Exploration Agency) with data type GSMaP Near-Real-Time which has a spatial resolution of $0.1^{\circ} \times 0.1^{\circ}$ lat/long and temporal resolution of 1 hour [2]. Water discharge data in Indonesia are still inadequate. This is due to various factors, including floods and landslides, as well as damage to hydrological temperature measurement stations caused by labor. One of the watersheds with insufficient data is the Temef watershed in TTS Regency, East Nusa Tenggara. Flood conditions during the rainy season in the Temef watershed caused material losses, especially in and around Malacca Regency. While the hot conditions in the dry season, resulting in drought. This indicates a problem of debit fluctuations. The calculation of water availability is necessary to determine the capacity of the water source [9].

The latest discharge analysis in the field of hydrology in Indonesia is the Artificial Neural Network Method [8]. Conveying Artificial Neural Network (ANN) is a form of artificial intelligence that has been widely applied in the field of water resources. The application of ANN in the field of water resources has been widely used for discharge analysis [17]. The rain-flow simulation method in discharge analysis can describe the hydrological process. Hence, the quality and quantity of rainfall data become the main consideration to acquire high accuracy of estimated discharge in a river [4-6]. Rainfall will be divided into several processes, some will experience evaporation, others become surface runoff, and some become infiltration and percolation [3]. The stages of building an Artificial Neural Network (ANN) model are training and testing [16]. The ANN (Artificial Neural Network) method is expected to identify the characteristic parameters of watersheds and most appropriately used in areas such as an East Nusa Tenggara Province, especially areas with low rainfall [15].

\section{Materials and Methods}

\subsection{Materials}

The research objects reviewed were TRMM JAXA data and rainfall stations located in South Central Timor Regency and North Central Timor Regency. There are 3 observation rainfall stations in the object of research, namely Nifukani, Batinifukoko, and Noelnoni (Figure 1).

Data in the research includes TRMM JAXA Data (2009-2018) GSMaP_NRT Version 6 which can be accessed through TRMM JAXA (ftp://hokushai.eorc.jaxa.jp), rainfall data obtained from the Public Works Office of East Nusa Tenggara Province (2009-2018), TMA discharge data (2009-2018), topographic and administrative map data sourced from the Public Works North Central Timor District Office. 


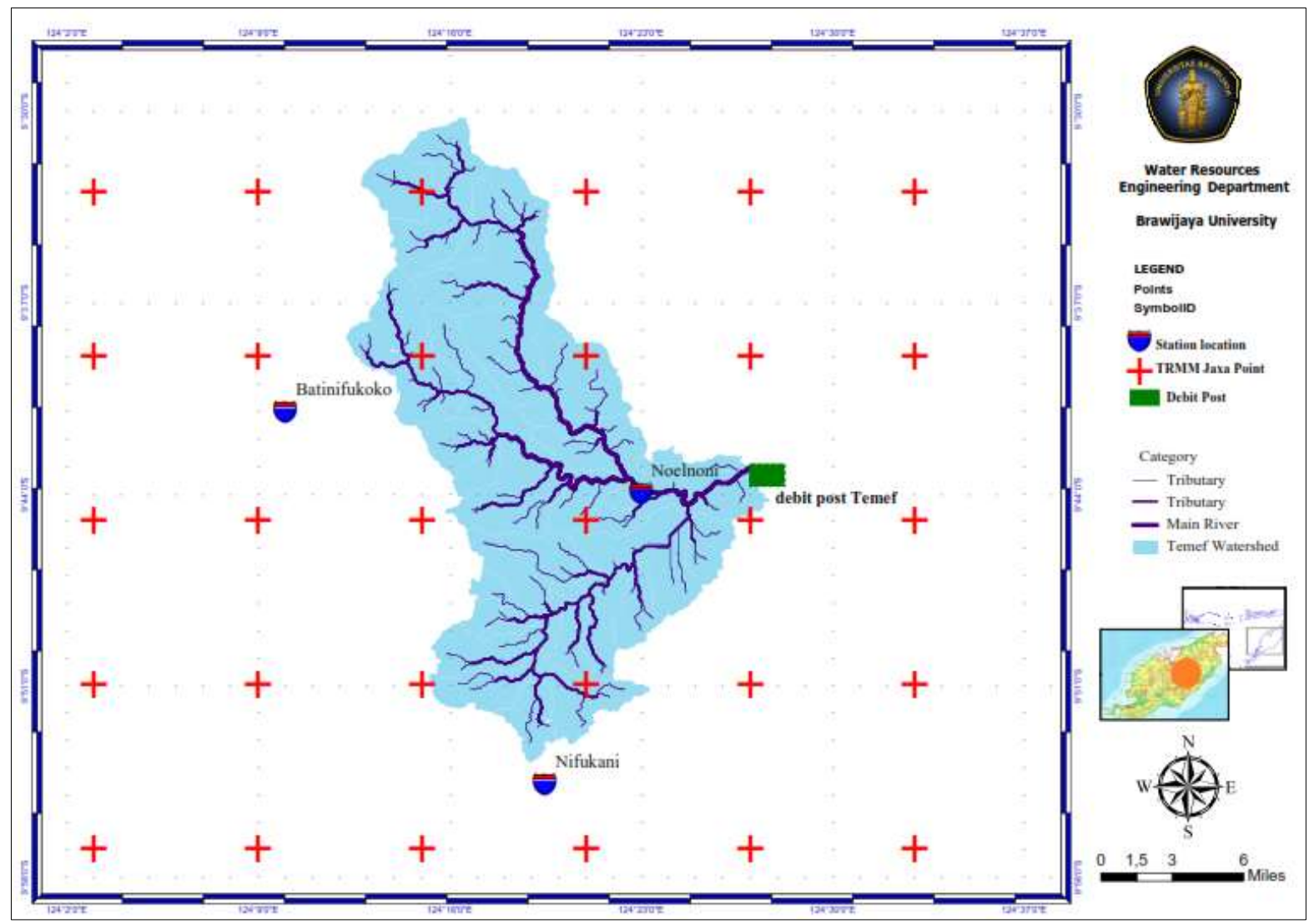

Figure 1. Temef Watershed - Timor Tengah Selatan Regency

\subsection{Methods}

\subsubsection{Hydrological Analysis}

\section{a. Consistency Test}

The purpose of the consistency test is to determine the irregularities that occur in each rain station post with the other rain station posts in the vicinity, this test uses a double mass curve for observation and TRMM JAXA stations $[3,9,18]$.

\section{b. Homogeneity Test}

The homogeneity was employed to ensure the number of populations to be measured is homogeneous. The homogeneity test was conducted on both observation stations and TRMM JAXA rainfall data includes trend absence test, stationary test, and persistence test $[3,9,18]$.

\section{c. Regional Rainfall}

Analysis of average rainfall area has an objective to obtain a value that presents the amount of rain in one particular region. The Thiessen Polygon method was used to analyze average areal rainfall [9].

\subsubsection{Statistical Analysis}

Statistical analysis includes calibration analysis, verification, and validation using statistical analysis [9], this analysis uses several statistical functions including the following: 
a. Nash Sutcliffe Efficiency (NSE) :

$$
N S E=1-\frac{\sum_{i=1}^{n}\left(x_{i}-y_{i}\right)^{2}}{\left(x_{i}-y_{i}\right)^{2}}
$$

With:

$\mathrm{Xi}=$ observation data (actual data)

$\mathrm{Yi}=$ estimation data (estimation result data)

$\mathrm{Xi}=$ average observation data

$\mathrm{N}=$ the number of data

b. Correlation coefficient

$$
r=\frac{n \sum_{i-1}^{n} x_{i} y_{i}-\sum_{i-1}^{n} x_{i} \sum_{i-1}^{n} y_{i}}{\sqrt{n \sum_{i-1}^{n} x_{i}^{2}-\left(\sum_{i-1}^{n} x_{i}\right)^{2}} \sqrt{n \sum_{i-1}^{n} y_{i}^{2}-\left(\sum_{i-1}^{n} y_{i}\right)^{2}}}
$$

$\mathrm{Xi}=$ observation data (actual data)

$\mathrm{Yi}=$ estimation data (estimation result data)

$\mathrm{N}=$ the number of data

c. Root mean squared error (RMSE)

$$
\begin{aligned}
& R M S E=\sqrt{\frac{\sum_{i-1}^{n}\left(x_{o b s, i}-y_{\text {model }, i}\right)^{2}}{n}} \\
& \mathrm{Xi}=\text { observation data (actual data) } \\
& \mathrm{Yi}=\text { estimation data (estimation result data) } \\
& \mathrm{N}=\text { the number of data }
\end{aligned}
$$

d. Relative error

$$
\begin{aligned}
K R & =\frac{\sum_{i-1}^{n}(x-y)}{\sum y} \times 100 \\
\mathrm{Xi} & =\text { observation data (actual data) } \\
\mathrm{Yi} & =\text { estimation data (estimation result data) }
\end{aligned}
$$

\subsubsection{Artificial Neural Network (ANN)}

ANN (Artificial Neural Network) analysis uses a Matlab program that serves to model field debit data $[3,15]$. This data input consists of rainfall, amount of rainy day, and runoff coefficient data. The present study employed the Backpropagation method which is a method to solve complicated problems because it has a good level of accuracy $[16,17]$.

\section{Results and Discussion}

\subsection{TRMM and Observation Data}

Based on the results of TRMM JAXA analysis and observation obtained graphs of the relationship of the two data. The graph and comparison shows that observation rains occur higher than TRMM rain for conditions with high rain intensity at the end and the beginning of the year, this happened at three rainfall stations (Figure 2) 


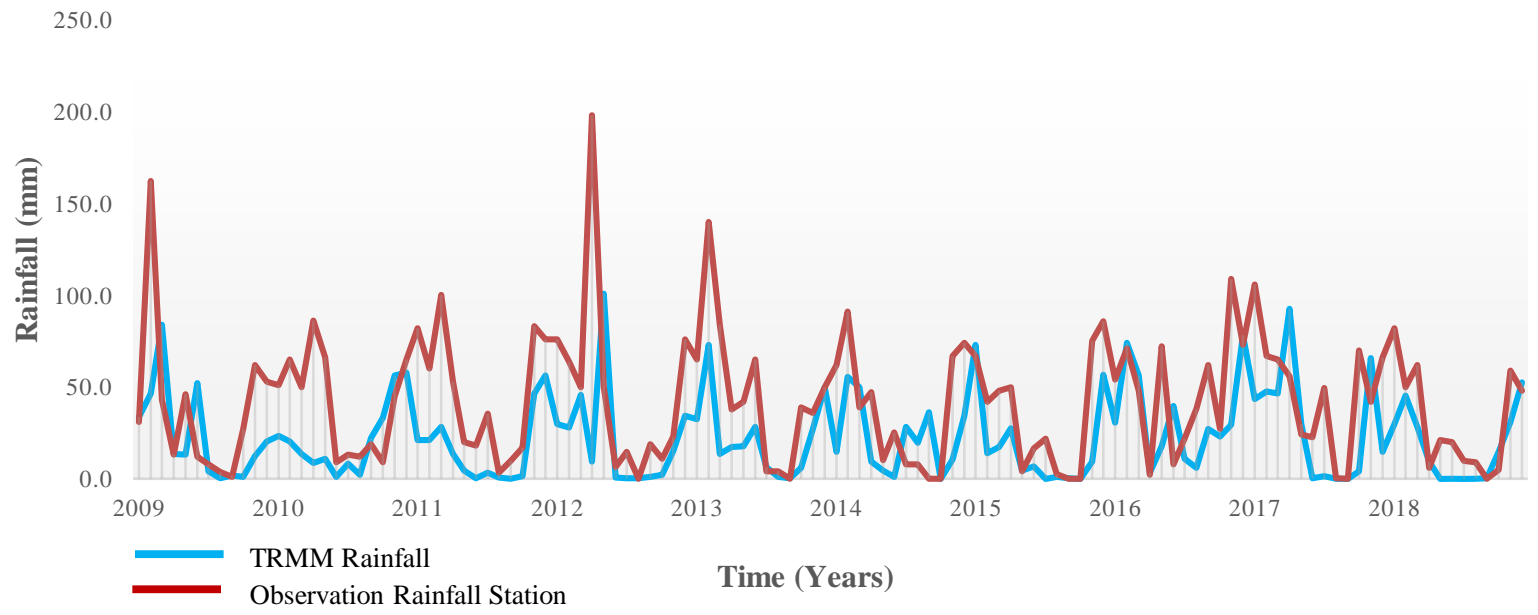

Figure 2. Graph Observed Rainfall Data and TRMM JAXA Batinifukoko Station

Result in the comparison of data from the Batinifukoko Station and TRMM station shows that the TRMM data is quite low, the resulting data are less than $100 \mathrm{~mm}$, this data is relatively consistent every year, while the observation data shows that rain data varies with an intensity of up to $200 \mathrm{~mm}$ (Figure 3).

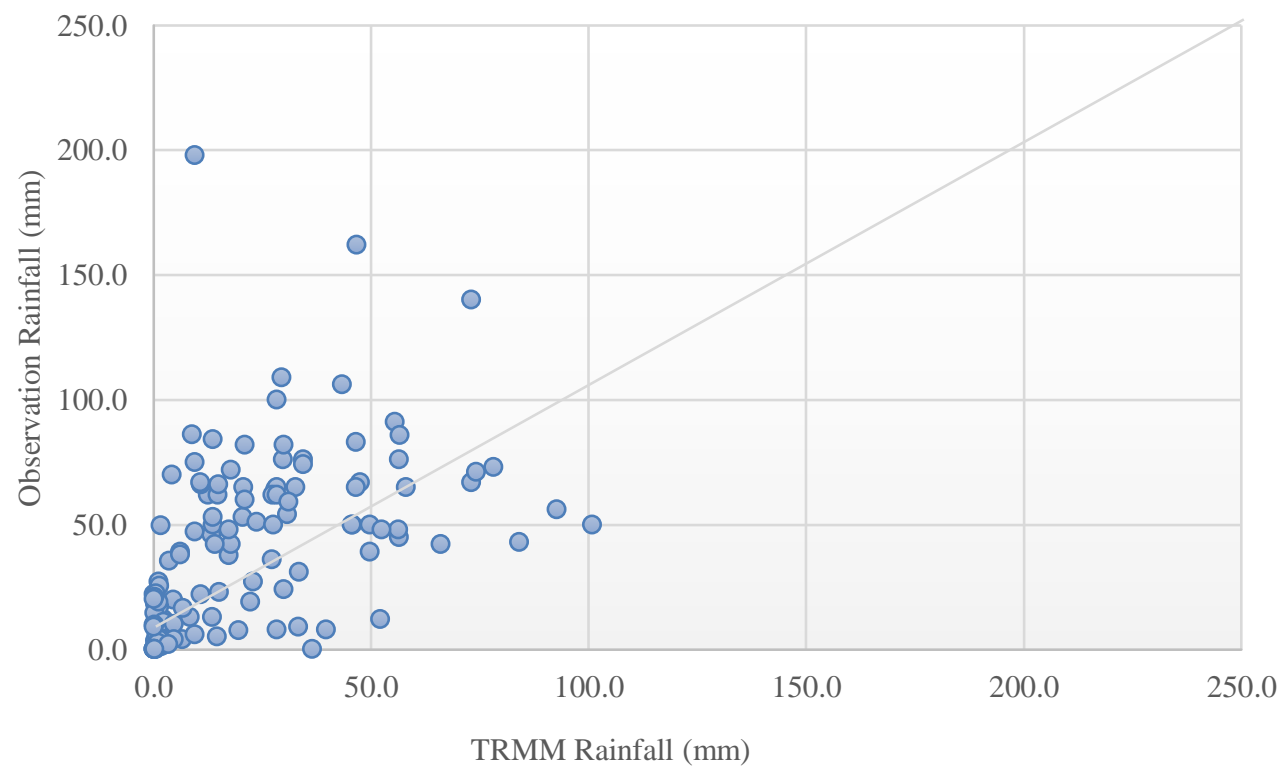

Figure 3. Comparison of Observed Rainfall Data and TRMM JAXA Batinifukoko Station

The results of the observation rainfall graph and TRMM rainfall for the Nifukani station show low rainfall data at the TRMM station when the rainfall at the observation station is high (Figure 4). And comparing the distribution of TRMM rainfall data and observation that are less consistent, results of TRMM rainfall are below $100 \mathrm{~mm}$, observation rainfall intensity reached $100 \mathrm{~mm}$ to 200 $\mathrm{mm}$ (Figure 5) 


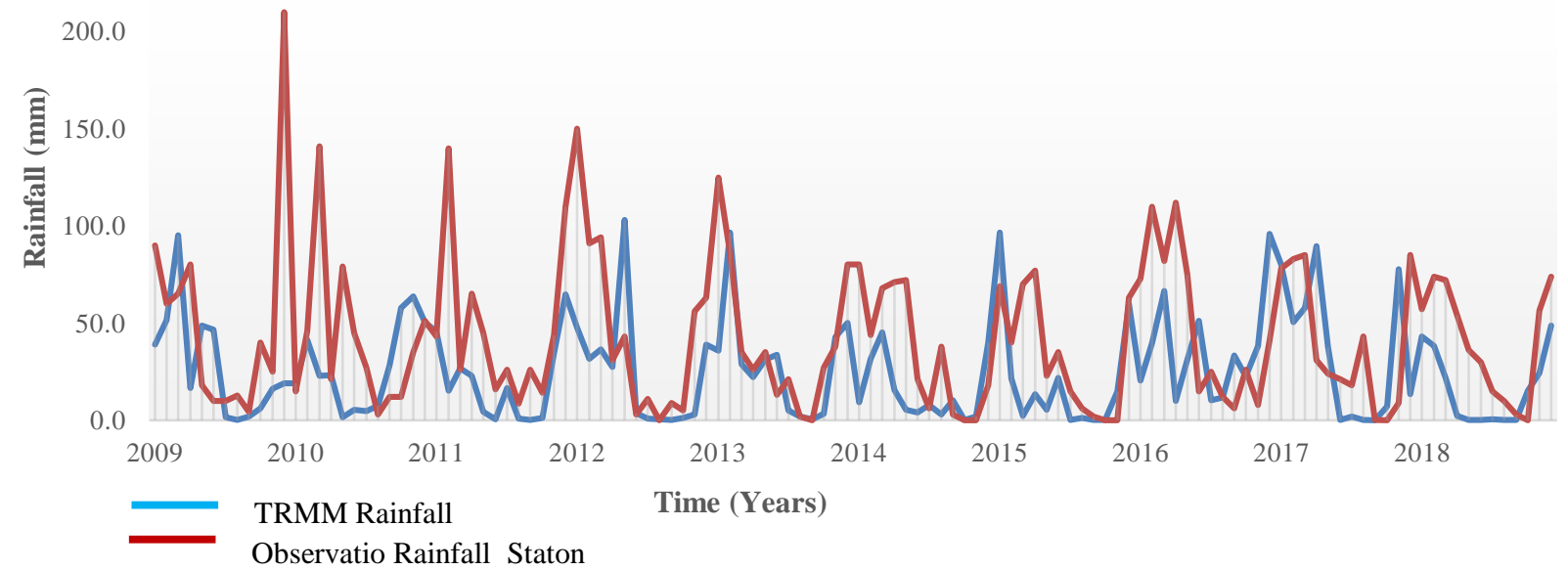

Figure 4. Graph Observed Rainfall Data and TRMM JAXA Nifukani Station

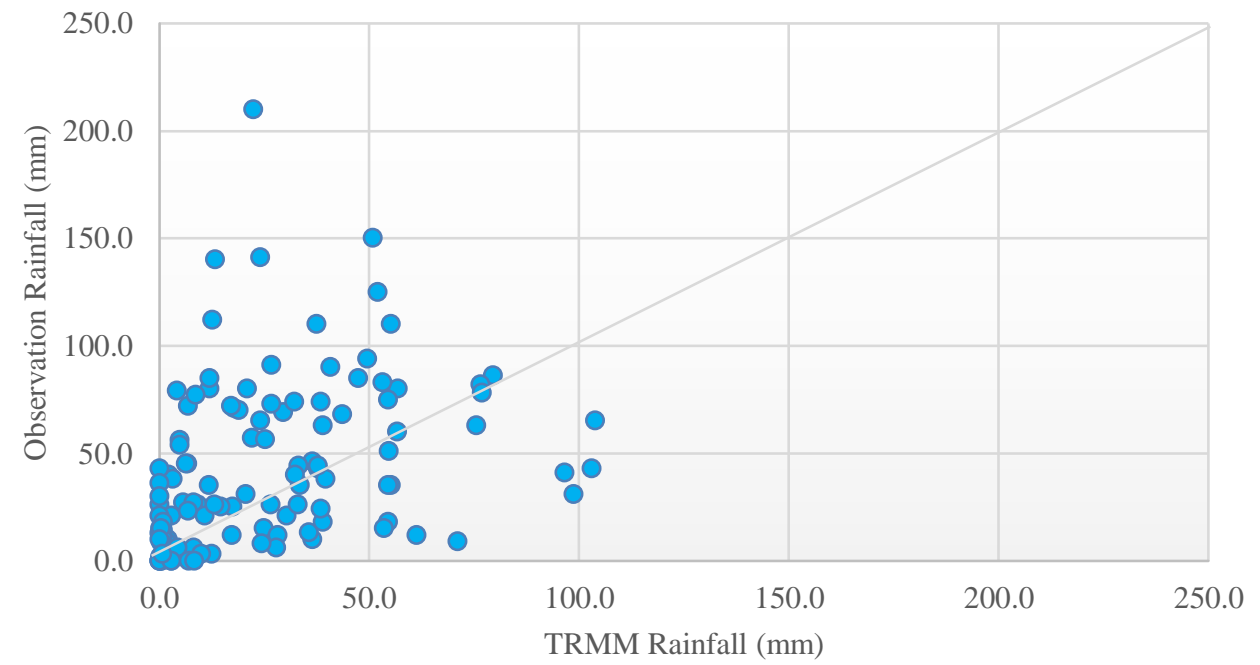

Figure 5. Comparison of Observed Rainfall Data and TRMM JAXA Nifukani Station

The results of the observation rainfall graph and TRMM for the Noelnoni station show low rainfall data at the TRMM station when the rainfall at the observation station is high (Figure 6). And comparing the distribution of TRMM rainfall data and observation that are less consistent (Figure 7) 


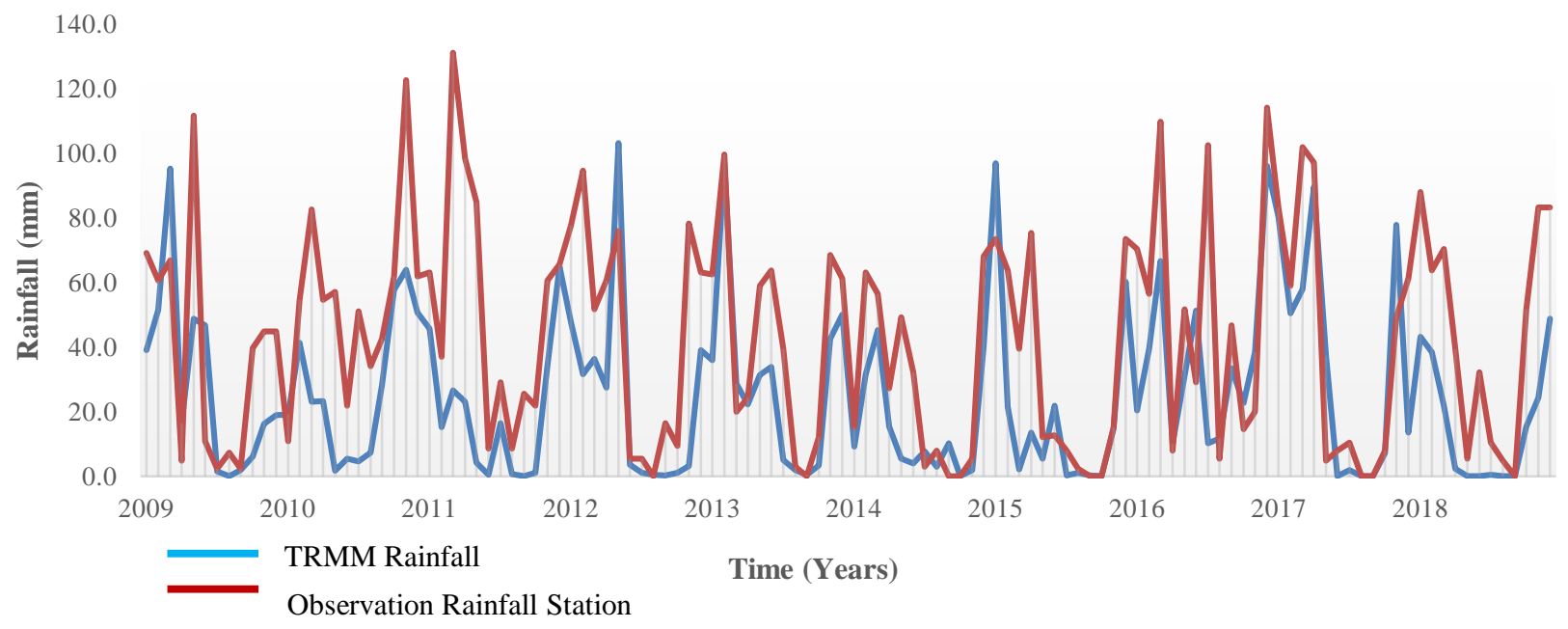

Figure 6. Graph Observed Rainfall Data and TRMM JAXA Noelnoni Station

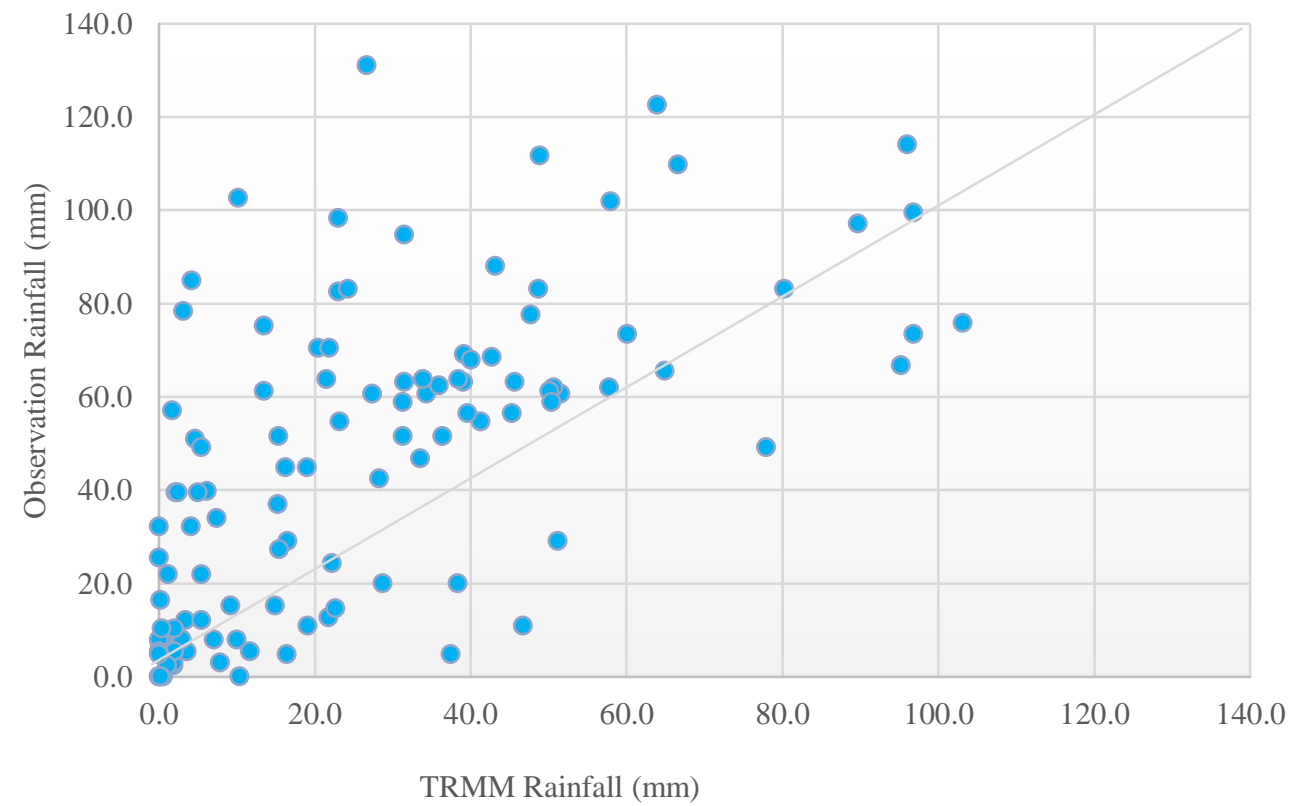

Figure 7. Comparison of Observed Rainfall Data and TRMM JAXA Noelnoni Station

\subsection{Data Correction}

Data calibration was conducted upon uncorrected TRMM rainfall data and corrected TRMM rainfall data by dividing the data into 4 groups with a comparison of 10 years of data or uncorrected data and 7:3 years, 8:2 years, 9:1 years. TRMM rain data analysis is done by calibration method with data length for 10 years with uncorrected data, obtained observation rain data relationship for 10 years and TRMM JAXA data, namely "Weak". Obtained several statistical analysis values, namely Root Mean Squared Error $($ RMSE) $=31.934$; Nash Sutcliffe Efficiency $(\mathrm{NSE})=-0.285$; Relative Error $(\mathrm{KR})=74.022 \%$ and Correlation Coefficient $(\mathrm{R})=0.542$. So based on the results above it is necessary to re-verify to get equations with good interpretation value (Table 1).

Based on calibration analysis of uncorrected TRMM data with rain station post data with four methods, namely RMSE, NSE, Relative Error, and Correlation Coefficient it can be concluded that calibration results show "weak" interpretation. Calibration analysis of 10 years, 9 years, 8 years, and 7 
years, as well as validation analysis of rain data of 3 years, 2 years, and 1 year were conducted to obtain correction equations for rain data (Table 2).

Table 1. Data Calibration Summary Results

\begin{tabular}{|c|c|c|c|c|c|}
\hline \multirow[b]{2}{*}{ Period } & \multicolumn{2}{|c|}{ Calibration } & \multirow[b]{2}{*}{ Validation } & \multirow[b]{2}{*}{ Equation } & \multirow{2}{*}{$\begin{array}{c}\text { Selected } \\
\text { Equation } \\
\text { Type }\end{array}$} \\
\hline & $\begin{array}{l}\text { Numberof } \\
\text { Years }\end{array}$ & $\begin{array}{l}\text { Value } \mathrm{R}^{2} \\
\text { Verification }\end{array}$ & & & \\
\hline \multirow{4}{*}{ Montly } & 7 Years & 0.3077 & 3 Years & $\begin{array}{c}y=-0.0142 x^{2}+1.71 x+ \\
20.03\end{array}$ & Polynomial \\
\hline & 8 Years & 0.2980 & 2 Years & $\begin{array}{c}y=-0.0121 x^{2}+1.572 x+ \\
20.101\end{array}$ & Polynomial \\
\hline & 9 Years & 0.3032 & 1 Year & $\begin{array}{c}y=-0.0123 x^{2}+1.555 x+ \\
20.222\end{array}$ & Polynomial \\
\hline & 10 Years & 0.3184 & - & - & - \\
\hline
\end{tabular}

The Scatter plot validation results for each rain data are shown in the graphic image of the rainfall relationship below, this graph illustrates the results of equations obtained from validation of 3 years, 2 years, and 1 year. Figure 8 Figure 9 and Figure 10 showing the scatter plot validation graph.

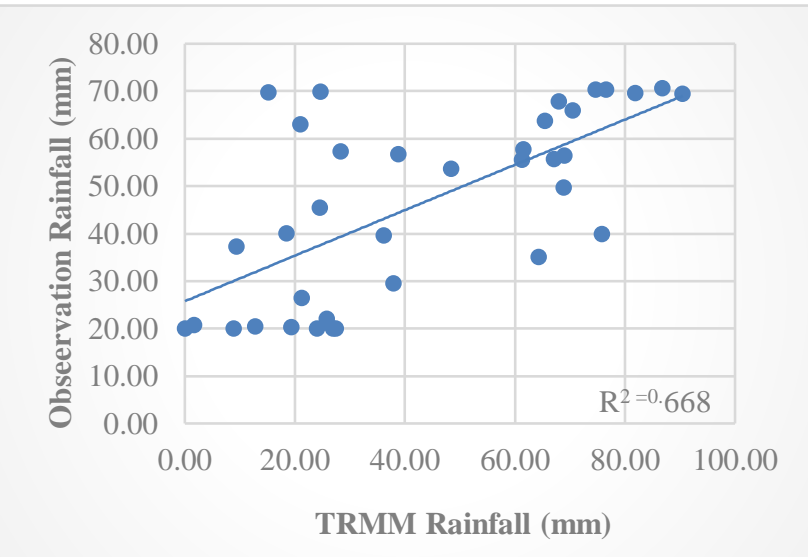

Figure 8. Scatter plot Validation For correct data period 3 years Polynomial equations

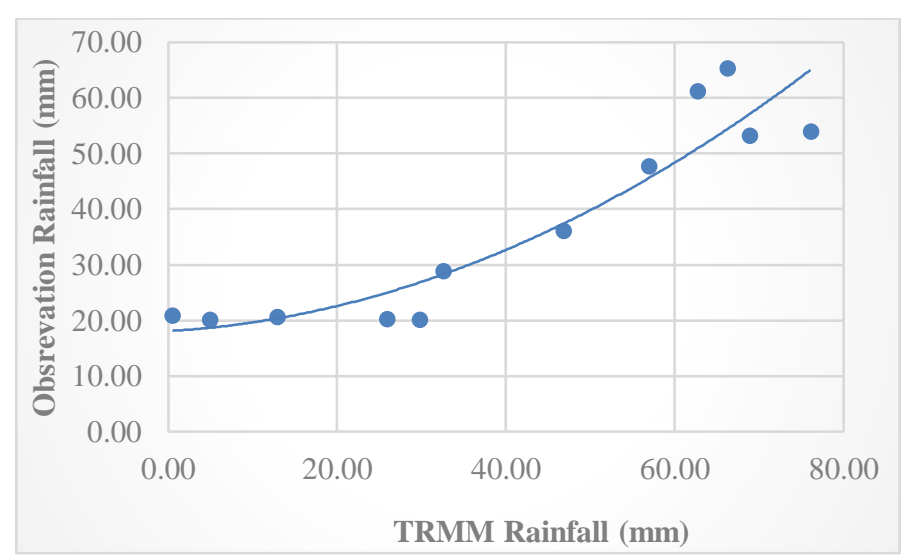

Figure 10. Scatter plot Validation For correct data period 1 year Polynomial equations

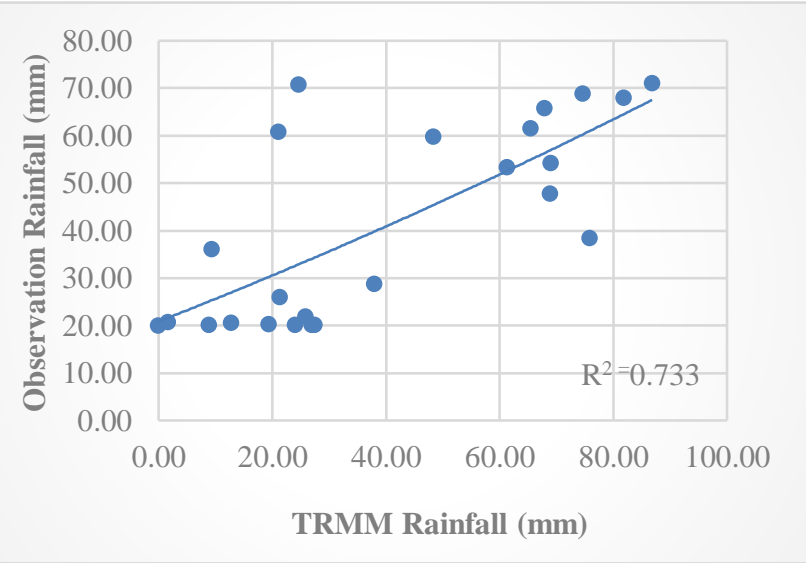

Figure 9. Scatter plot Validation For correct data period 2 years Polynomial equations 
Table 2. Data Validation Summary Results

\begin{tabular}{|c|c|c|c|c|c|c|c|}
\hline \multirow{2}{*}{ Period } & \multirow{2}{*}{$\begin{array}{l}\text { Number } \\
\text { of Years }\end{array}$} & \multirow{2}{*}{ RMSE } & \multicolumn{2}{|r|}{ NSE } & \multirow{2}{*}{$\mathrm{KR}$} & \multicolumn{2}{|r|}{$\mathrm{R}$} \\
\hline & & & Value & Interpretation & & Value & Interpretation \\
\hline \multirow{4}{*}{ Monthly } & 3 Years & 20.16 & 0.674 & Meet & $7.03 \%$ & 0.668 & Weak \\
\hline & 2 Years & 18.65 & 0.782 & Meet & $3.44 \%$ & 0.733 & Strong \\
\hline & 1 Year & 13.699 & 0.920 & Meet & $2.62 \%$ & 0.877 & Very Powerful \\
\hline & 0 Year & 31.933 & -0.285 & $\begin{array}{c}\text { Does Not } \\
\text { Meet }\end{array}$ & $74.02 \%$ & 0.542 & Weak \\
\hline
\end{tabular}

From Table 2, The results of the calibration data for 9 years Verification and Validation 1 year create equal relationships $\mathrm{R}^{2}$ higher than others (7:3. 8:2. and 10 Years). The verification results to get the relationship $\mathrm{R} 2=0.877$. shows that the correlation is very good, that is above 0.60 . The data validation obtained the equation $\mathrm{y}=-0.0123 \mathrm{x} 2+1.555 \mathrm{x}+20.222$ (Polynomial Equation) with the interpretation of "Very Strong". The RMSE value is influenced by the amount of data and the difference between the observed data and the simulation data. The longer the data range, the greater the effect of the RMSE value. Validation with a data length of 3 years has the greatest value compared to data lengths of 2 years and 1 year.

The method of 1 year, 2 years, and 3 years indicates the interpretation of "Fulfilling". Based on the criteria of the NSE method, if the NSE value is closer to the value of 1 then the better the model. While the result of validation is $>0.5$. So it can be concluded that the results meet and the model is good for validation of 1.2 and 3 years.

The amount of Relative Error value of correcting data validation in all periods and time frames ranges from about $2.00 \%-7.00 \%$ so it can be said that corrected TRMM rainfall data has a relatively small error rate when compared to observation post rainfall data.

The result of the Correlation Coefficient method shows the relationship between TRMM rainfall data and observation post rainfall data is relative "Very Strong" in the period and the time span of 1 Year. The coefficient value is closer to the value of 1 . the better the correlation between the two data.

Based on the analysis resulting from the comparison between uncorrected TRMM data validation and corrected TRMM data, it can be concluded that the corrected TRMM data is closer to the rainfall value of the rain station post which is considered as the correct data. Thus, it can be concluded that TRMM rainfall data can be used as an alternative hydrological data for use in planning in the field of water resources.

The result of 9 years of data verification and 1-year data validation is considered as the result with the best data relationship so that it is used for advanced analysis. Equation $\mathrm{y}=-0.0123 \mathrm{x} 2+1.555 \mathrm{x}+$ 20.222 (Polynomial Equation) is used to correct TRMM rain data that occurs.

\subsection{Artificial Neural Network Analysis}

Rain data are simulated by a discharge that comes out using the Artificial Neural Network (ANN). From the data is prepared variables for input Matlab data (Figure 11), sample data, and target data containing variables, including corrected TRMM rainfall, flow coefficients, and rainy days. The data are simulated to get the discharge data that occurs.

The results of the analysis showed train data validation data and test data and show the same pattern, proved that the result of the iteration is good (Figure 12). The results of the Neural Network Training State Analysis are good, it is obtained from the number of iterations (Figure 13) and reliability of discharge with a correlational relationship for Training was 0.989 , and Test results are 0.99 "Very Good" (Figure 14). 


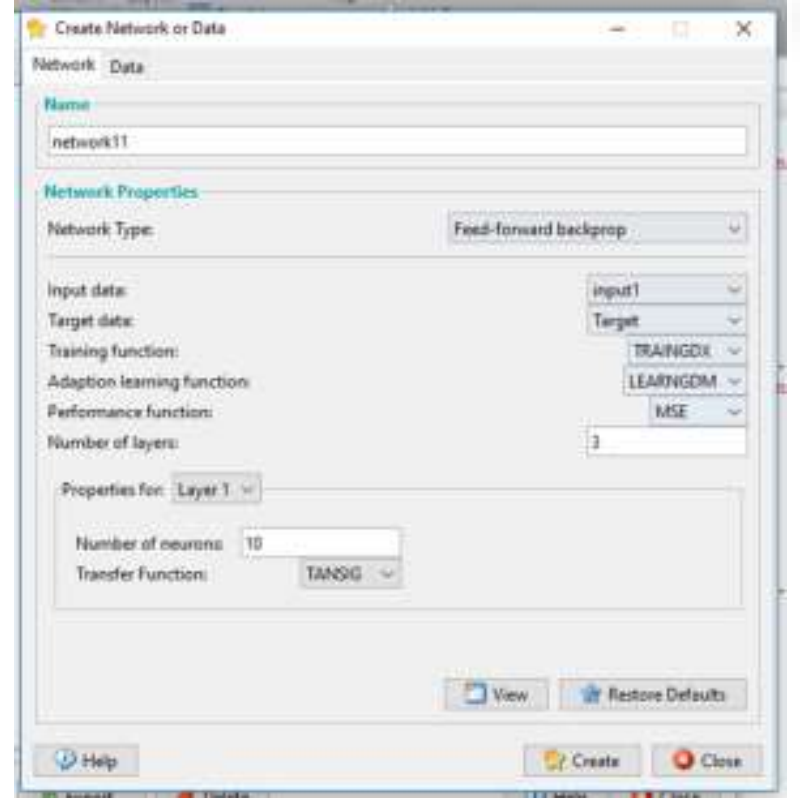

Figure 11. Backpropagation

Method in Artificial Neural

Network analysis

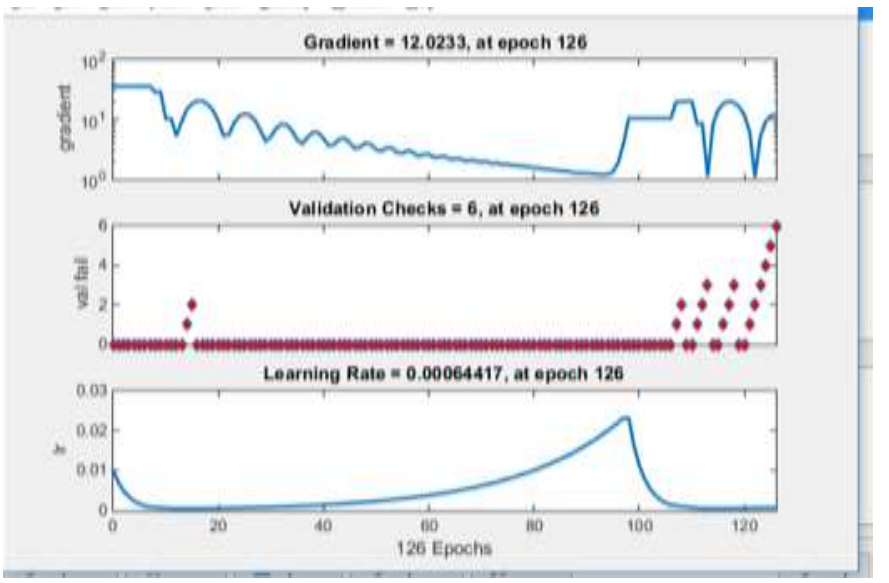

Figure 13. Results of Neural Network Training State Analysis

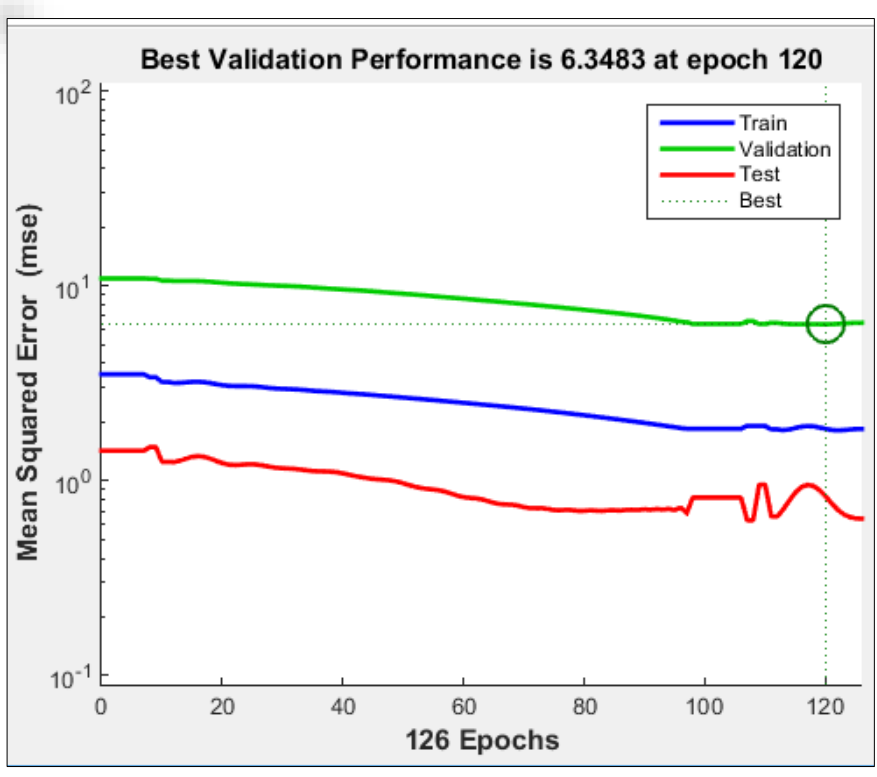

Figure 12. Results of Neural Network Performance Analysis
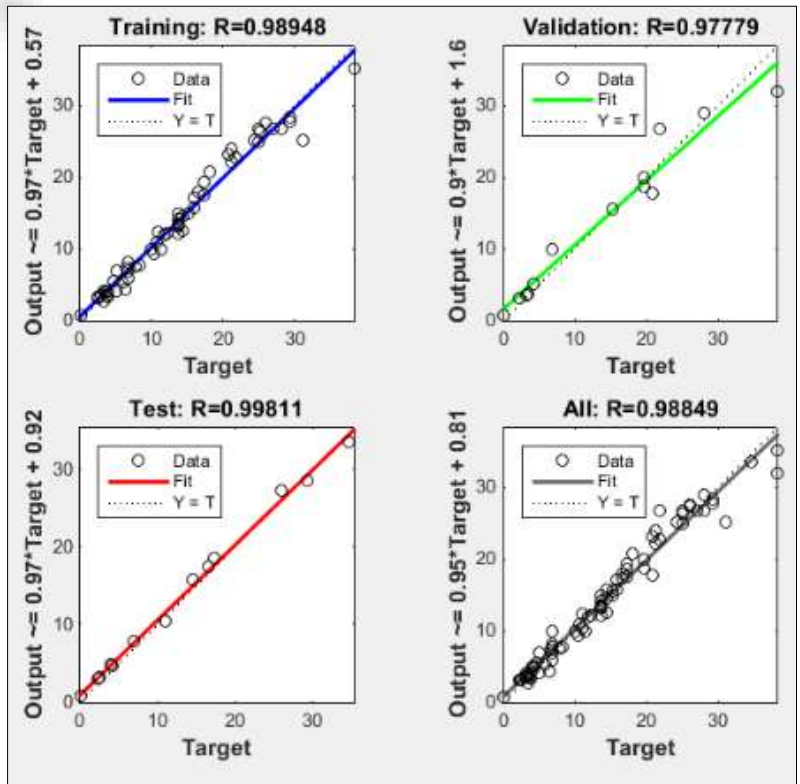

Figure 14. Results of Neural Network Regression Analysis

Table 3. Result of Summary of TRMM JAXA Rain Data Validation (9:1) to Debit

\begin{tabular}{|c|c|c|c|c|c|c|}
\hline \multirow{2}{*}{\multicolumn{2}{|c|}{ Data }} & \multicolumn{2}{|r|}{ NSE } & \multirow{2}{*}{$\mathrm{KR}$} & \multicolumn{2}{|r|}{$\mathrm{R}$} \\
\hline & & Value & Interpretation & & Value & Interpretation \\
\hline Debit & 10 Years & 0.887 & Meet & $9.04 \%$ & 0.827 & Strong \\
\hline
\end{tabular}

From Table 3, These results are validated with sample data that will look at the relationship of data used results, so that it can be concluded that corrected TRMM Rain has a "Strong" interpretation 
where the NSE relationship is 0.887 . The correlation coefficient of discharge and precipitation is 0.827 and the relative error is 9.04 so that the TRMM data has a correlation relationship with the debit data that occurs in the field.

\section{Conclusion}

From the results of the analysis can be concluded that the relationship of TRMM JAXA satellite rainfall to observation data shows a pattern and intensity approaching between the two rainfall data, but observation rainfall data shows higher intensity than TRMM data. Overestimate occurs in observational rainfall compared to TRMM rainfall, especially during the rainy season in the end and the beginning of the year. TRMM satellite data tend to underestimate in the rainy season and is quite close to observation data in the dry season. The results of verification and validation with a "Very Strong" interpretation are indicated by the results of 9 years verifiable and 1-year validation where the results of verification of 9 years data show a correlation between observed rainfall and TRMM JAXA rainfall is 0.877. 1-Year Validation indicates "Very Strong" Interpretation with an NSE value is 0.920, Relative Error is $2.63 \%$, and RMSE is 13.699 with selected equation is a polynomial equation $(\mathrm{y}=-$ $0.0123 \times 2+1.5553 \mathrm{x}+20.222$ ). The results of 8 data verification and 2 -year validation showed a "Strong" interpretation. Where the correlation between Observed rainfall and TRMM rainfall was 0.733. 2-Year Validation indicates "Strong" Interpretation with an NSE value is 0.782. Relative Error is $3.44 \%$, and RMSE is 20.16 with the selected equation is a polynomial equation $(\mathrm{y}=-0.0121 \mathrm{x} 2+$ $1.572 \mathrm{x}+20.101)$. The results of 7 years of verification and 3 years of validation showed a "Weak" interpretation. Where the correlation between observational rainfall and TRMM rainfall was 0.668. 3Year Validation obtained NSE value is 0.674 , Relative Error $7.03 \%$, and RMSE is 20.16 with the selected equation is a polynomial equation $(\mathrm{y}=-0.0142 \mathrm{x} 2+1.71 \mathrm{x}+20.03)$. While for data results without correction shows a "Weak" result with a low correlation value of 0.542 and a large relative error of $74.02 \%$. Results of discharge in ANN method based on rain from TRMM JAXA (Japan Aerospace Exploration Agency) simulation training and artificial neural network testing showed "Strong" results where NSE relationship was 0.887. Coefficient of discharge and precipitation correlation was 0.872 and relative error was 9.045 .

\section{Reference :}

[1] Badan Pusat Statistik (BPS), 2018. Propinsi Nusa Tenggara Timur Dalam Angka, 0215-2223

[2] Earth Observation Research Center (EORC), Japan Aerospace Exploration Agency (JAXA), (2018) USER'S GUIDE FOR Global Rainfall Map in Near-Real-Time by JAXA Global Rainfall Watch (GSMaP_NRT), Version 3.2

[3] Ery Suhartanto, Evi Nur Cahya, Lu'luil Maknun, Analisa Limpasan Berdasarkan Curah Hujan Menggunakan Model Artifical Neural Network (ANN) di Sub Das Brantas Hulu, Jurnal Teknik Pengairan, Vol 10. No 2 (2019), pp. 134-144. DOI https://doi.org/10.21776/ub.pengairan.2019.010.02.07

[4] Harisuseno, D. (2020a). Kajian Kesesuaian Rumus Intensitas Hujan dan Kurva Intensitas Durasi Frekuensi ( IDF ) di Wilayah Kampus Universitas Brawijaya, Malang. Media Komunikasi Teknik Sipil, 26(2), 247-257

[5] Harisuseno, D., Suhartanto, E., \& Cipta, D. M. (2020). Rainfall-Streamflow Relationship using Stepwise Method as a Basis for Rationalization of Rain Gauge Network Density. International Journal of Recent Technology and Engineering, 8(5), 3814-3821. https://doi.org/10.35940/ijrte.e6617.018520

[6] Harisuseno, D., Wahyuni, S., \& Dwirani, Y. (2020). Penentuan Formulasi Empiris Yang Sesuai Untuk Mengestimasi Kurva Intensitas Durasi Frekuensi. Jurnal Teknik Pengairan, 11(1), 38 48. https://doi.org/10.21776/ub.pengairan.2020.011.01.06

[7] Harisuseno. (2020). Meteorological Drought and its Relationship with Southern Oscillation Index (SOI), Civil Engineering Journal, Vol. 6, No. 10, pp. 1864-1875. 
[8] Hasihardaja, Sugeng (2005) Pemodelan Curah Hujan-Limpasan Menggunakan Artificial Neural Network (ANN) dengan Metode Backpropagation, Civil Engineering Journal Vol.12 No 4.

[9] Lufi Suryaningtyas, Suhartanto Ery, Rispiningtati, Hydrological Analysis of TRMM (Tropical Rainfall Measuring Mission) Data in Lesti Sub Watershed, Jurnal, Vol 3. No 1 (2020), pp. 18-30 DOI https://doi.org/10.21776/ub.civense.2020.00301.3

[10] Mamenun et al (2014) Validasi Dan Koreksi Data Satelit TRMM Pada Tiga Pola Hujan Di Indonesia, Jurnal Meteorologi Dan Geofisika vol. 15 no. 1-2014 : 13-23

[11] Maulana, H., Suhartanto, E., \& Harisuseno, D. (2019). Analysis of Water Availability Based on Satellite Rainfall in the Upper Brantas River Basin. International Research Journal of Advanced Engineering and Science, 4(2), 393-398.

[12] Oldeman, R.L., Irsal Las, and Muladi. 1980. The agro-climatic maps of Kalimantan, Maluku, Irian Jaya, and Bali West and East Nusa Tenggara Contrib. No.60. Centr. Res. Inst.Agrc. Bogor.

[13] Priyanto Dwi, 2016 Strategies To Return East Nusa Tenggara As a Source of Beef Cattle, Jurnal Litbang Pertanian Vol 35 No 4 December 2016:167-168

[14] Sahoo, A.K., Shefeld, J., Pan, M., Wood, E.F., 2015. Evaluation of the tropical rainfall measuring mission multi-satellite precipitation analysis (TMPA) for assessment of large-scale meteorological drought. Remote Sens. Environ. 159. 181-193.

[15] Syarief Fathoni, Very Dermawan, Ery Suhartanto, Analisis Efektivitas Kerapatan Jaringan Pos Stasiun Hujan Di Das Kedungsoko Dengan Menggunakan Jaringan Saraf Tiruan (Artificial Neural Network), Jurnal Teknik Pengairan, Vol 7. No 1 (2016), pp. 129 - 138.

[16] Tarigan, G, H et al,. (2014) Analisa Prediksi Data Debit Runtun Waktu Menggunakan Jaringan Syaraf Tiruan Algoritma Backpropagation (Studi Kasus Das Indragiri); Jom Engineering Faculty; Volume 1 NO. 2 October 2014.

[17] VD Oktoprianica, E Suhartanto, S Wahyuni, Analisa Curah Hujan Terhadap Debit Limpasan Menggunakan Metode Jaringan Syaraf Tiruan (Jst) Backpropagation Di Das Welang, (2020) Jurnal Teknik Sipil 9 (2), 301-314.

[18] Welkis et al, (2020), Characteristics of Flood Water Level Based on Hydrologic Soil Group Analysis in Temef Watershed, IOP Conference Series: Earth and Environmental Science, 437 (2020) 012005. 